Ms Colleen Sampson

Cape Peninsula University of Technology

Professor Janet Condy

Cape Peninsula University of

Technology

DOI: http://dx.doi. org/10.18820/2519593X/pie. v34i2.7

ISSN 0258-2236

e-ISSN 2519-593X

Perspectives in Education

2016 34(2): 83-96

(c) UVIUFS

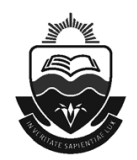

\section{One teacher's experiences of teaching reading in an urban multi-grade foundation phase class}

\begin{abstract}
Many teachers have been confronted by the demanding situation of teaching two or more year groups in the same classroom although data on this multi-grade phenomenon is scarce. The purpose of this study attempts to answer the research question: What are the experiences of one foundation phase teacher when teaching reading in an urban multi-grade foundation phase class? The theoretical framework central to answering the research question was based on Lave and Wenger's (1991) community of practice. The literature review highlights the physical setting of urban multi-grade classrooms, debates the limitations and benefits of urban multi-grade teaching and finally briefly outlines the old and the new South African curriculum policies with regard to reading. A qualitative interpretive case study research design was formulated to explore the complex phenomenon of reading practices in the foundation phase. Data were collected using interviews and observations, which were video recorded. In conclusion, this unique study reveals that despite evidence from provincial tests indicating poor reading results in multi-grade teaching of reading, this teacher proved that reading in urban multi-grade classes does work. In her classroom, she showed that multi-grade teaching of reading fosters the emotional, intellectual, social and academic well-being of learners.
\end{abstract}

Keywords: Foundation phase, interpretive, multi-grade, qualitative, reading, urban

\section{Introduction}

The phenomenon of urban multi-grade teaching is not as common as in rural areas (Bouysee, 2002). This unique study explores the reading practices of a teacher in an urban multi-grade class in the foundation phase (FP).

This study evolved out of the researcher's concern for the status of reading in South African urban multigrade schools. The researcher was motivated by her own context as an FP teacher and agrees with the statement that the most important task of FP teachers is to ensure that all learners learn to read (NDoE, 2003). For the past twenty-three years, her aim has been to help learners acquire the cognitive and perceptual skills necessary for their scholastic and literacy development. The researcher believes that the early stage of a child's school life is crucial 
for the development of literacy skills. Reading, in particular, is a fundamental competency and the core of our curriculum. Every learning area depends on fluent reading and the ability to comprehend text. Failure in reading strongly predicts failure in all other academic subjects (Whitehurst \& Lonigan, 2008). Therefore the significance of this project is that the researcher supports the idea that education structures should equip rural and urban learners with advanced literacy skills in order to cope with the demands in the latter stages and make the transition from 'learning to read' to 'reading to learn' (Heugh, 2006: 9).

After examining the 2015 Western Cape Education Department (WCED) Systemic Test results for grade 3 language, it was alarming to note that the provincial pass percentage was $42.2 \%$. The area, 'Reading and Viewing', on which this research focuses, was $42.6 \%$, and the pass percentage for quintile 4 schools, where data for this research project were collected, was only $37.5 \%$. With these poor pass rates and a dearth of research on urban multi-grade schooling, the researcher felt compelled to explore the teaching of reading in this area.

\section{Community of practice (CoP)}

Since this study was conducted in an urban multi-grade environment, where there are typically three grades in one class, it was appropriate to use the perspectives of socio-constructivist theorists, Lave and Wenger (1991). They contend that communities of practice are everywhere and that we are generally involved in a number of them; whether at work, school, home or in our civic and leisure interests. Communities of practice are formed by people who engage in a process of collective learning in a shared domain of human endeavour (Wenger, 2007). In this research project, the learners sat in their grade groups and assisted each other where they could across grades. Sometimes a stronger grade 2 learner helped a weaker grade 3 learner.

Over time, this collective learning results in practices that reflect the pursuit of our enterprises and the social relations. Wenger (1998: 45) states that these practices are thus the property of a kind of community created over time by the sustained pursuit of a shared enterprise. The term, 'communities of practice' is therefore fitting. He further depicted a community of practice as the interplay between the physical setting of the institution of learning, its curriculum and accreditation and the practice of teaching and learning within the community (1998: 63).

Lave and Wenger (1991) contend that learning occurs through active engagement within contextual experiences. In other words, learning is embedded within activity, context and culture. More recently, there has been a shift of focus from acquisition to participation. Hager (2005: 23) argues that the two approaches of learning, as acquisition and learning as participation are not mutually exclusive. While participation itself is a process, the learner belongs more to the community by acquiring the right characteristics or products of learning.

Brown, Collins and Duguid (1989) support Lave and Wenger's propositions by stating that the conventional schooling systems are inherently inauthentic domains where knowing is separated from doing. Knowledge is therefore uprooted from its proper context in a community of practice and presented as "abstract, decontextualised and formal concepts". They believe that activities are integral to cognition and learning and that cognitive apprenticeship can provide the authentic practice through activity and social interaction. Lave (1988) agrees with the above researchers and affirms that "knowledge is not separable from, or supplementary to, learning and cognition; it should be an integral part of what is learned". 


\section{Literature review}

The literature review focuses on the teaching of reading in an urban multi-grade FP class. The uniqueness of this urban setting is highlighted with regard to reading skills and multi-grade classroom management.

\section{Reading}

In the CAPS document, the languages programme is integrated across the curriculum in oral work, reading and writing (CAPS, 2011: 6). Time allocation for Home Language in the FP is 6 hours and the First Additional Language is 4 hours for grade R-2 and 5 hours for grade 3 . In grades $1-3$, reading takes place in the reading and writing focus time. It is here, through clear, focused lessons that learners are taught to be effective readers and writers. Daily time is set-aside for lessons covering different strategies for reading: shared reading, group-guided reading, paired reading, independent reading and phonics (CAPS, 2011: 8). A gap exits in this document as no indication is provided for teaching multi-grade classes. Teachers in these classrooms need to be flexible in how they manage their time and the skills taught.

In order to teach reading effectively, readers "need to be engaged in appropriate-level, high-quality texts that foster enthusiasm and critical thinking" (Dreher, 2003: 25). Learners need opportunities to read and re-read developmentally appropriate books. These books should "capture their interests, address curriculum content, be based on cultural diversity and provide sufficient instructional opportunities" (Compton-Lilly, 2008: 668). By allowing learners to read on their own, offering feedback and assistance as they demonstrate the need for it, teachers will be able to determine what their learners need and at what stage they are.

Narratives surround children from their earliest language experiences. Young children experience narrative stories through shared book reading at home or at school. As children listen to stories, a number of cognitive processes are at work at the word, sentence and text levels (Oakhill \& Cain, 2007: 4). These skills are important precursors to reading comprehension (Kendeou et al., 2009; Mckeown, Beck \& Blake, 2009). Thus, narrative listening comprehension skills are developing well before a child is able to read and comprehend texts independently. The development of narrative listening comprehension may lead to strategies that are more effective in fostering this ability in young learners and promoting later reading comprehension (Lepola et al., 2012: 260). Sadik (2008) found that storytelling enhanced the integration of language skills, developed language abilities (Houston, 1997) and improved learners' listening comprehension (Neugebauer \& Currie-Rubin, 2009). Children have the ability to connect to other people by imagining the thoughts and feelings of characters in picture books as part of making sense of and responding to stories. This ability to imagine the thoughts, feelings and intentions is known as social imagination (Johnson, Johnson \& Holubec, 1993: 428). Carpendale and Lewis (2002: 79) call it social understanding.

If one accepts that comprehension is the goal of reading, then vocabulary is the foundation of reading comprehension - referring to the body of words one needs to communicate effectively. This includes knowing the meaning of words and the manner in which to pronounce them correctly. If a learner has a limited understanding of vocabulary, they will have a limited understanding of the concepts. This in turn will limit the understanding of the content. It is well established that learners who comprehend well tend to have good vocabulary (Anderson \& Freebody, 1981). This correlation, however, does not mean that teaching vocabulary will increase readers' comprehension. 
As beginners in reading, children have to make sense out of words they see in print. Literacy researchers, Raphael, Pardo and Highfield (2002: 107) believe that there is a strong correlation between reading and vocabulary knowledge; meaning learners who have a large vocabulary are usually good readers. Vocabulary can also be learned incidentally during storybook reading or when listening to others. It is true that if one reads extensively, one is likely to be a good reader. Children make sense of words they see in print. They therefore learn to recognise the letters and syllables that make up the words (Stahl, 2004: 63). Phonics teaches children the systematic and predictable relationship between sounds of a language and their spelling (Rose, 2006: 27).

Comprehension forms the core of reading. Wilkinson and Son (2011: 364) found that comprehension instruction is most effective when learners flexibly use reading and thinking strategies in more collaborative contexts. In order to improve memory and comprehension of text, teachers use various approaches. They generate questions about ideas while reading; encourage learners to construct mental images representing ideas in text; read into story characters or problems encountered by characters and attempt solutions (Pearson \& Fielding,1991).

\section{Urban multi-grade teaching}

A dearth exists in current literature into the research of urban multi-grade teaching; hence many of the references seen in this section may be fairly dated.

Multi-grade teaching refers to the teaching of learners of different ages, grades and abilities in the same classroom by one teacher (Joubert, 2010). Literature uses many different terms to describe this kind of teaching; namely, 'multi-level', 'multiple class', 'composite class', 'vertical group' and 'family classes' (Katz, 1995: 11). In South Africa, there is no policy standardising which grades are combined (Brown, 2008). Brunswic and Valerien (2004: 45) maintain that multi-grade teaching is often established out of necessity. The reasons may be based on economic, social, political or demographic circumstances (low population density, resulting from rural-urban migration).

While South Africa has one of the largest and more advanced economies in Africa, it remains a highly unequal society. It has a vibrant first world economy on the one hand, and a larger, informal, rural and urban economy on the other, in which poverty remains rife (Makoro, 2007: 54). In this study, the district in which the multi-grade school was located reflected typical characteristics of urbanisation: poverty was ubiquitous. Demographics such as unemployment and poverty are regular features of this community. Beineke, Foldesy and Maness, (2004: 2) highlight the fact that "urban parents are often less able to contribute to their children's schoolwork due to economic demands". The crime rate for semi-urban areas is believed to be higher than for rural areas and there appears to be a "strong association between failing in school and delinquent behaviour" (Fullwood et al., 2001: 5).

Managing a multi-grade classroom is difficult because there is more than one grade level in the classroom (Juvane, 2005). According to Kyne (2005), teachers must be aware of different ways of grouping children, the importance of independent study areas where learners can go when they have finished their work and approaches to record keeping which are more flexible than those prevalent in the mono-grade classroom.

Contrary to rural areas, multi-grade teaching in urban areas has advantages for teachers and learners. The benefits of teaching in a multi-grade classroom are primarily related to 
the way that instruction is organised. Stone (1998: 234) maintains that vertical cross-grade groupings of learners can provide cognitive and emotional benefits. Irrespective of how teachers divide their classrooms, effective multi-grade teaching should be based on the recognition that children learning in one classroom differ in terms of development. In view of this more flexible approach, learners of mixed abilities and age groups in multi-grade classrooms can be allowed to move through the system at a pace appropriate to them (Loeto, 2010).

Research has shown that the cooperative approaches to instruction in many classroom settings have a positive impact on learners. These learners tend to have higher self-esteem and are confident socially (Johnson et al., 1993; Stahl \& Van Sickle, 1992). In cooperative learning, the teacher designs the social interaction structures as well as learning activities (Kagan, 1989: 12). Learners work together to ensure that all members in their groups have learnt and assimilated the same content. They therefore maximise their own and each other's learning when they work together (Johnson et al., 1993).

Goto and Schneider (2010) suggest that being in a class with younger learners encourages older learners to work harder to stay ahead of younger classmates. Learners gain confidence when they are occasionally given responsibilities for helping younger or less able learners in their class. Children are expected to work independently for longer periods than they would in a mono-grade classroom.

Teachers may increase their motivation by applying multi-age philosophies to classrooms by adapting their curriculum to meet all their learners' needs. Teachers are able to focus on the progress of individual learners rather than their own progress in moving through the adopted textbooks and sticking to rigid course calendars. This is in contrast to a common curriculum, which does not focus on individual abilities (Aina, 2001).

Although many teachers agree with the philosophies of the multi-age classrooms, some are sceptical of multi-age programmes because of difficulties implementing and operating the programmes. The first barrier is usually dissatisfaction and rejection by parents. Mixing their children with children of other ages raises concerns about the quality of instruction. Schools should influence families, families ought to influence schools and both affect and are affected by the communities in which they are located (Christenson \& Sheridon, 2001: 39).

\section{Methodology}

This study used a qualitative interpretive case study design in order to answer the research question: What are the experiences of one foundation phase teacher when teaching reading in an urban multi-grade class?

This Afrikaans medium school had an enrolment of 790 learners and was located in the Northern District of Parow in the Western Cape. The majority of learners came from low socioeconomic backgrounds. This school accommodated a diverse population of learners, from the Democratic Republic of Congo and Zimbabwe. Since it was classified as a quintile 4 school, Grant (2013) considered it a fee-paying school yet they did not receive food from the nutrition programme. There was only one multi-grade class in the entire school.

Mrs T was purposively selected, as she was the only teacher in the school who taught in an urban multi-grade setting (Cohen, Manion \& Morrison, 2007). She taught thirty-four learners in one grade 1, 2 and 3 multi-grade class. She had twenty-four years of general teaching experience with an additional five years of urban multi-grade teaching. 
Learners attending this school experienced few of the challenges that face equivalent learners in rural situations. One third of the learners were within walking distance from their school, the majority had to travel to school using public transport such as taxis. Although most learners came from low-income households, parents were prepared to pay travelling costs in order to provide their children with a better education. These elements are in stark contrast to equivalent rural schools where transport is a substantial obstacle. Few of the parents of learners in this urban multi-grade school were highly educated yet most were literate. They were in a better position to assist their children than their rural counterparts.

In order to gain a deeper insight into this urban multi-grade classroom, interviews and observations were video recorded and used as data. The interviews were conducted in Afrikaans after school hours on the school premises, so that the teaching process was not disrupted. Mrs T was interviewed twice since part of the first recording was inaudible. Five classroom observations were conducted during school time, over a period of nine weeks, every second Monday. Since the researcher was a bilingual class teacher herself, permission was granted from her own principal and the principal of the school to visit on Monday mornings from 8.00am-9.30am. The first visit to the school was an introductory visit to meet the teacher and learners. In order for the researcher to gain an understanding of all reading practices during the observation sessions, Mrs T agreed to amend her timetable so she would do reading early in the morning while the researcher was there. Bloor and Wood (2006: 71) outline the importance of accessing what participants actually do, rather than what they say they do. The multiple sources of evidence collected in this research project provided triangulation (Yin, 2008).

This qualitative inquiry was inductively analysed for meaning. Before the analysis began, data from all the interviews and observational notes were translated from Afrikaans to English, then transcribed and back transcribed. Mrs $\mathrm{T}$ was asked to comment on the clarity and correctness. The process of analyses involved "examining words, sentences and paragraphs in order to organise, decode, interpret and theorise data on an ongoing, emerging basis" (Henning, van Rensburg \& Smit, 2007: 127). This was done repeatedly in an attempt to understand the nuances of the data in an attempt to link the units of meaning to the research question. Three categories including: stories, vocabulary and phonics as well as comprehension emerged. By identifying the relationship among the codes in the cluster, four superordinate themes became evident (Henning et al., 2007: 104).

Ethical clearance was obtained from the Western Cape Education Department (WCED) and the university granting the researchers permission to conduct their research. Consent letters addressed to the principal and the class teacher were collected. Mrs T was informed about the research process and could withdraw at any time. Her confidentiality was protected by referring to her as Mrs T.

\section{Findings}

The three main literacy themes will be discussed with particular emphasis on the four further superordinate themes relating to multi-grade teaching, which included classroom management, curriculum adaptation, the value of peer tutoring and parental support. 


\section{Stories}

Mrs T structured the classroom management of reading lessons by starting with whole-class instruction followed by grade-groups. Working within communities of practice, their gradegroups, made teaching reading easier for Mrs T rather than using ability groups.

Mrs T was observed using a traditional fable, 'The Little Red Hen'. Few of the learners would have understood this story from their urban environment. She had the entire class (grades 1, 2 and 3) sitting on the carpet repeating the verbal patterns and actions. To engage the learners, Mrs T showed the learners pictures - to engage the grade 1 learners, as she read the story and encouraged an exchange of ideas. The manner in which Mrs T asked higher order questions compelled the learners to offer opinions and to delve into the feelings of the main character. From the observations, these are examples, of how Mrs T asked questions to engage the learners in the story:

Mrs T: Why do you think the other animals said 'no' to The Little Red Hen when she asked for help?

Mrs T: How do you think The Little Red Hen felt when she had to do all the work herself?

Mrs T: How do you think The Little Red Hen felt when all the animals wanted to eat the bread she had made?

Both grade 2 and grade 3 learners were able to answer the questions, as the response required them to relate to their own experiences. She felt strongly that children should be encouraged to think critically and consider their own actions in similar situations. She stated,

Most of the time I tell simple stories and then we have a time of discussion so that my children can talk about their own experiences.

Mrs T was asked how she adapted the curriculum for all three classes. She stated that she not only had to plan for all her subjects and three different reading lessons but she had to adapt the curriculum to suit the needs of her learners,

Mrs T: It is impossible to get through the entire curriculum for each grade, so I teach what I think is important.

When Mrs T was asked how she used peer tutoring. She referred to an instance where she had a grade 2 learner who struggled with sounds. She placed this learner with the grade 1 learners "to give her the foundations of sounds". According to Mrs T, this was the reason she did not have "ability groups". She emphasised that, while having older learners helping junior learners was a benefit of a multi-grade class, "the tough part is monitoring all the different reading levels".

Mrs T expressed her discontent with the lack of parental support. Many of the learners in Mrs T's class lived with their grandparents during the week and went home to their parents for weekends. She disclosed,

It is a struggle with parents even to do the little homework that I send. They do not understand what is expected even though I give them guidelines.

In answer to a probing question about communicating with parents, Mrs T revealed that she "sent home message books but some parents are literate only in French or Xhosa, they 
do not respond". She added that many of these parents are unemployed. "They get involved when it is too late", when their child has to repeat a grade.

\section{Vocabulary and phonics}

Mrs T managed her classroom by teaching vocabulary and phonics in grade group communities. In the interview, she explained,

The grade $1 s$ start with single consonant sounds and vowels and at this stage they are able to build simple words. The grade $2 s$ are adding prefixes and suffixes to words and the grade 3's are writing sentences to illustrate the meanings of words.

She engaged her learners in games such as matching pictures to words, while assessing their phonic knowledge and learners participated enthusiastically. In the interview, she mentioned that she tried to vary her lessons so that learners could remember and apply the words in the reading activities. She stated,

I sometimes play games using the new vocabulary, just to make it more interesting.

When teaching vocabulary and phonics, Mrs T adapted the curriculum according to the needs of her learners and the grade groups. Mrs T was observed working with the grade 1 learners who were tasked with having to identify initial or final sounds of words. By contrast, the progression in the lesson with the grade 2 learners was evident: they were expected to identify digraphs in words. Playing games where they had to choose the odd word from a series of related words developed their auditory skills, for example:

Mrs T: grey, saw, mat, late. Which word does not belong?

Grade 2: mat, teacher

Mrs T: You are correct but why does the word mat not belong?

The grade 3 learners were required to write sentences on whiteboards from the teacher's dictation. They decoded the more difficult words as they wrote them, emphasising the sounds. An example from the observation indicates,

Mrs T: We are going to the hall on Friday

Grade 3: We are go-ing to the $h$-all on Friday

In the interview, Mrs T referred to how she used peer tutoring. She remembered an instance where she had a grade 2 learner who struggled with sounds. She placed this learner with the grade 1 learners "to give her the foundations of sounds". She emphasised that, having older learners helping junior learners was a benefit of a multi-grade class.

The lack of parental support of homework was difficult for Mrs T. The grade 1 and grade 2 classes had high frequency sight words, which they needed to learn at home. The grade 3 learners had spelling lists for their weekly spelling tests. Mrs T complained about the lack of adult supervision as the homework was seldom completed satisfactorily.

In the interview, Mrs T made reference to the fact that her learners did not always recall the words.

Researcher: How are the parents encouraged to help their children read?

Mrs T: There is very little parental support at home so children don't always learn. 


\section{Comprehension}

This area focused on the four higher order-thinking skills as described in the PIRLS document (Howie et al., 2012: 45) and she managed the classroom within communities of practice, grade groups. Mrs T stated that she compiled her own reading resources because this enabled her to 'pitch' them at the level of her own learners. The researcher observed:

The grade 1 learners were expected to apply their basic knowledge of comprehension in the form of a sequence story. They showed the development of a story by arranging pictures in the correct order.

The grade 2 learners were expected to respond to the meaning of words in context. Mrs T presented sentences with three options. The learners selected the appropriate answer from these possibilities.

The grade 3 learners worked independently at their desks. They were given a prepared comprehension passage from a book called "Doen en Leer" and were told to answer the questions in full sentences. In the interview, the researcher asked,

Researcher: How do you manage the teaching of comprehension?

Mrs T: The thing about teaching comprehension strategies is that much of it is taught incidentally. The nice part about teaching a multi-grade class is that they pick up from one another, so you don't have to re-teach the same concepts.

As a multi-grade teacher, Mrs T was responsible for teaching other learning areas in addition to reading. In the interview she stated that she not only had to plan for all her subjects and three different comprehension lessons but she had to adapt the curriculum to suit the needs of her learners:

It is impossible to get through the entire curriculum for each grade, so I teach what I think is important.

Further adaptations were made as Mrs T used peer tutoring. Peer tutoring (Lave \& Wenger, 1991) was corroborated in the video recording where one grade 3 boy was observed assisting four grade 2 learners with sequencing sentences. This could be seen as best practice in a multi-grade setting because learning is enhanced through co-participation (Lave \& Wenger, 1991). Mrs T revealed that the parental support is lacking. She stated,

I send home message books but some parents are literate only in French or Xhosa, they do not respond. Many of these parents were unemployed. They get involved when it is too late as when their child has to repeat a grade.

Kohen et al., (2008) link low income and unemployment to parenting that is less consistent and less stimulating. Yet parental involvement in learners' literacy practices is seen as being more influential than the family's social class or the level of education of parents (Clark \& Rumbold, 2006: 24).

\section{Discussion}

Despite the dearth of research published on effective multi-grade teaching, this urban FP multigrade teacher, Mrs T, not only used the multi-grade setting to her and her learners' advantage but she enjoyed her teaching. This is one exemplary study, which advocates and supports urban multi-grade teaching. Mrs T was able to teach reading successfully to all her learners. 
She skilfully managed her classroom as a community of practice (Lave \& Wenger, 1991) where she cared for the individual needs of her learners and attempted to make the learning environment as stimulating and as safe as possible. She attempted to contextualise the fictional characters in the story and make the learning personal to the lived authentic lives of her learners. She experienced that CoPs existed in the sense of peer tutoring. Learners assisted each other, even if it was the older learners who benefited from the younger learners (Lave \& Wenger, 1991).

She knew how to adapt her curriculum to the needs of her learners; she incorporated emergent reading skills using a more kinaesthetic approach with the grade 1 learners while the grade 2 and 3 learners were working on grade appropriate comprehension passages. She realised that she would never have sufficient time to teach all the literacy skills stated in the CAPS document, so she risked selecting certain skills, which she thought were more important and which her learners needed in order to move from "learning to read" to "reading to learn" (Heugh, 2006: 9). She purposefully taught reading in whole groups and in grade groups using peer tutoring. She enjoyed teaching in a multi-grade classroom where the more abled learners helped the challenged learners.

Although the lack of parental support was challenging for Mrs T she acknowledged and understood the situation, consequently worked sensitively and mindfully with her learners, never berating them for not completing homework tasks. Many of the learners lived with their grandparents who had neither been exposed to books nor read.

\section{Conclusion}

Education officials often dismiss multi-grade teaching. The challenges are too great to give particular attention to these settings. There is a lack of pedagogical material to support this teaching. Classrooms are often characterised by a lack of organisation, inefficient use of time and a failure to present knowledge in a logical sequence. Peer tutoring is not practised and teachers seem to miss opportunities to utilise the range of abilities present in the classroom.

With this in mind, the researcher was not convinced that urban multi-grade teaching of reading could be successful. There was limited international and national research, on the pedagogy of urban multi-grade teaching in developing countries to draw from. However, after completing this unique research, against the background of the poor WCED results of reading for quintile 4 schools (37.5\%), being guided by Lave and Wenger's (1991) theoretical framework of CoPs, acknowledging the ills of this particular urban environment and grappling to make sense of the findings; it became clear that in Mrs T's class, she fostered the emotional, intellectual, social and academic well-being of her learners. This is one rare research project that promotes urban multi-grade teaching of reading.

This research project has documented how multi-grade classes can benefit some learners socially, emotionally and academically. It is recommended that teacher-trainers, provincial and national education officials read this paper and become advocates for using Lave and Wagner's CoP for teaching reading in multi-grade and multi-group environments, with specific attention to teaching in diverse communities and using peer tutoring. 


\section{References}

Aina, O.E. 2001. Maximizing learning in early childhood multi-age classrooms: Child, teacher, and parent perceptions. Early Childhood Education Journal, 28(4), 219-225. http://dx.doi. org/10.1023/A:1009590724987

Anderson, R.C. \& Freebody, P. 1981. Vocabulary knowledge. In J.T. Guthrie (Ed.). Comprehension and teaching: research reviews. Newark, DE: International Reading Association. pp. 77-117.

Beineke, J., Foldesy, G. \& Maness, D. 2004. Comparing and contrasting rural and urban schools: A national perspective and an international model. Conference paper presented at the European Teacher Education Network. The University of Greenwich, Greenwich, UK. 3 - 5 October 2004.

Bloor, M. \& Wood, F. 2006. Keywords in qualitative methods: A vocabulary of research concepts. London: Sage Publishers. http://dx.doi.org/10.4135/9781849209403

Bouysee, V. 2002. Les classes multi-grade seminaire interactif des responsables de planification. Paris: UNESCO.

Brown, B. 2008. Challenges in the use of multi-grade teaching to promote sustainable human development in South Africa. Commonwealth Youth and Development Journal, 6(2), 70-86.

Brown, J.S., Collins, A. \& Duguid, P. 1989. Situated cognition and the culture of learning. Educational Researcher, 18, 32-42. http://dx.doi.org/10.3102/0013189X018001032

Brunswic, E. \& Valerien, J. 2004. Multi-grade schools: Improving access in rural Africa? Available at www.unesco.org/iiep [Accessed 12 June 2011].

Carpendale, J. \& Lewis, C. 2002. Constructing an understanding of mind: The development of children's social understanding within social interaction. Behavioural and Brain Sciences, 27, 79-151.

Cash, T. 2000. Multi-grade teaching. London: University of London. Available at http://www. ioe.ac.uk/multigrade/fulltext7terrycash.htm. [Accessed 8 October 2012].

Chorzempa, B.F. \& Graham, S. 2006. Primary-grade teachers' use of within-class ability grouping in reading. Journal of Educational Psychology, 98, 529-541. http://dx.doi. org/10.1037/0022-0663.98.3.529

Christenson, S.L. \& Sheridon, S.M. 2001. Schools and families: Creating essential connections for learning. London: Guilford Press.

Cohen, L., Manion, L. \& Morrison, K. 2007. Research methods in education. $6^{\text {th }}$ ed. London: Routledge.

Compton-Lilly, C. 2008. Teaching struggling readers: Capitalizing on diversity for effective learning. The Reading Teacher, 61(8), 668-672. http://dx.doi.org/10.1598/RT.61.8.10

Dreher, M.J. 2003. Motivating struggling readers by tapping the potential of information books. Reading \& Writing Quarterly, 35, 386-406. http://dx.doi.org/10.1080/10573560308206

Fullwood, H., Gates, G. Pancake, A., \& Schroth, G. 2001. Rural and urban America. Rural Special Education Quarterly, 20, 1-12. 
Goto, K. \& Schneider, J. 2010. Learning through teaching and learning: Challenges and opportunities in facilitating student learning in food science and nutrition by using the interaction approach. Journal of Food Science Education. 9(1), 31-35. http://dx.doi. org/10.1111/j.1541-4329.2009.00087.x

Grant, D. 2013. WCED media release quintiles. Western Cape. Available athttp://www. education.gov.za [Accessed 12 April 2013].

Henning, E., van Rensburg, W. \& Smit, B. 2007. Finding your way in qualitative research. Pretoria: Van Schaik.

Heugh. K. 2006. Language and literacy issues in South Africa. In N. Rassool (Ed.). Global issues in language education and development: Perspectives from postcolonial countries. Clevedon: Mulitilingual Matters. pp. 187-218.

Houston, G. 1997. The power of story: What I have learned as a writer and teacher. The Reading Teacher, 50(5), 382-395.

Howie, S., van Staden, S., Tshele, M., Dowse, C. \& Zimmerman, L. 2011. PIRLS 2011: South African children's reading literacy achievement. Pretoria: Centre for Evaluation and Assessment.

Johnson, D.W., Johnson, R.T. \& Holubec, E.J. 1993. Circles of learning: Cooperation in the classroom. $4^{\text {th }}$ ed. Edina, MN: Interaction Books.

Joubert, J. 2010. Multi-grade teaching in South Africa. Commonwealth Education Partnerships. Available at http://www.cedol.org/wp-content/upload/2012/02/ [Accessed 14 May 2011].

Juvane, V. 2005. Redefining the role of multi-grade teaching: ADEA working group on the teaching profession - Education for Rural People in Africa: Policy lessons, options and priorities.

Kagan, S.1989. The structural approach to cooperative learning. Educational Leadership 47(4), 12-15.

Katz, L. 1995. Non-graded and mixed-age grouping in early childhood programmes. Available at http://www.ed.gov/databaseis/ERIC-Digests/ed351148html [Accessed 2 February 2013].

Kendeou, P., van den Broek, P. White, M.J. \& Lynch, J.S. 2009. Predicting reading comprehension in early elementary school: The independent contributions of oral language and decoding skills. Journal of Educational Psychology, 101(4), 765-778. http://dx.doi. org/10.1037/a0015956

Kohen, D.E. Leventhal, T., Dahinten, V.S. \& Mclntosh, C.N. 2008. Neighbourhood disadvantage: Pathways of effects for young children. Child Development, 79,156-169. http:// dx.doi.org/10.1111/j.1467-8624.2007.01117.x

Kyne, C. 2005. The grouping practices of teachers in small two-teacher primary schools in the Republic of Ireland. Journal of Research in Rural Education, 20(17), 1-20.

Lave, J. 1988. Cognition in practice: Mind, mathematics, and culture in everyday life Cambridge: Cambridge University Press. http://dx.doi.org/10.1017/CBO9780511609268

Lave, J. \& Wenger, E. 1991. Situated learning: Legitimate peripheral participation. Cambridge: Cambridge University Press. http://dx.doi.org/10.1017/CBO9780511815355

Loeto, B.M. 2010. Lessons on multi-grade education in Botswana. Paper presented at the Southern African Multi-grade Education Conference 2010. Paarl. 22-24 March. 
Lepola, J, Lynch, J., Laakkonen, E., Silvén M. \& Niemi, P. 2012. The role of inference making and other language skills in the development of narrative listening comprehension in 4-6 yearold children. Reading Research Quarterly, 47(3), 259-282.

Makoro, T. 2007. The political emancipation of women in South Africa and the challenge to leadership in the churches. Studies in World Christianity, 13(1), 53-56. http://dx.doi. org/10.3366/swc.2007.13.1.53

McKeown, M.G., Beck, I.L. \& Blake, R.G.K. 2009. Rethinking reading comprehension instruction for strategies and content approaches. Reading Research Quarterly, 44(4), 218-253. http://dx.doi.org/10.1598/RRQ.44.3.1

Neugebauer, R.S. \& Currie-Rubin, R. 2009. Read-aloud in Calca, Peru: A bilingual indigenous context. The Reading Teacher, 62(5), 396-405. http://dx.doi.org/10.1598/RT.62.5.3

Oakhill, J.V. \& Cain, K. 2007. Introduction to comprehension development. In K. Cain \& J. Oakhill (Eds.). Children's comprehension problems in oral and written language: A cognitive perspective. New York: Guilford. pp. 3-40.

Pearson, P. D. \& Fielding, L. 1991. Comprehension instruction. In R. Barr, M. Kamil,

P. Mosenthal \& P.D. Pearson (Eds.). Handbook of reading research. New York: Longman. pp. 815-860.

Raphael, T.E., Pardo, L.S. \& Highfield, K. 2002. Book club: A literature-based curriculum. 2nd ed. Littleton: Small Planet Communications, Inc.

Rose, J. 2006. Independent review of the teaching of early reading. Nottingham: DFES Publications.

Sadik, A. 2008. Digital storytelling: A meaningful technology-integrated approach for engaged student learning. Educational Technology Research and Development, 56, 487-506. http:// dx.doi.org/10.1007/s11423-008-9091-8

South Africa. National Department of Education. 2003. Revised national curriculum statement. Grades R-9. Policy document. Pretoria: Government Printer.

South Africa. National Department of Education. 2011. Curriculum and assessment policy statement. Pretoria: Government Printer.

Stahl, K.A.D. 2004. Proof, practice and promise: Comprehension strategy instruction in the primary grades. The Reading Teacher, 57, 598-601.

Stahl, R.J. \& Van Sickle, R.L. 1992. Cooperative learning in the social studies classroom: An introduction to social study. Bulletin, 87. Washington, DC: National Council for the Social Studies.

Stone, S.J. 1998. Creating contexts for middle-age learning. Childhood Education, 74(4), 234235. http://dx.doi.org/10.1080/00094056.1998.10521943

Vygotsky, L.S.1978. Mind and society: The development of higher psychological processes. Cambridge, MA: Harvard University Press.

Wenger, E. 1998. Communities of practice: Learning, meaning, and identity. Cambridge. University Press. http://dx.doi.org/10.1017/CBO9780511803932

Wenger, E. 2007. Communities of practice: A brief introduction. Communities of practice. Available at http://www.ewenger.com/theory/ [Accessed 15 March 2012]. 
Wertsch, J.V. \& Tulviste, P. 1996. L.S. Vygotsky and contemporary developmental psychology. In H. Daniels (Ed.). An introduction to Vygotsky. London: Routledge.

Western Cape Education Department. 2015. WCED systemic for grades 3, 6 and 92015 results. Cape Town: Western Cape Education Department.

Whitehurst, G.J. \& Lonigan, C.J. 2008. Child development and emergent literacy. 69(3). Available at http://onlinelibrary.wiley.com/doi10.1111/j.1467-8624.1998.tb06247.x/pdf [Accessed 12 March 2011].

Wilkinson, I.A.G. \& Son, E.H. 2011. A dialogic turn in research on learning and teaching to comprehend. In M.L. Kamil, P.D. Pearson, E.B. Moje \& P.P. Afflerback (Eds.). Handbook of reading research. 4, 359-387.

Yin, R.K. 2008. Case study research: Design and methods. $4^{\text {th }}$ ed. Thousand Oaks, CA: Sage Publishers. 